\title{
QUANDO AS CÉlulaS SÃo CURRÍCUlOS: UMA ABORDAGEM SOBRE O RISCO DA DISCRIMINAÇÃO GENÉTICA
}

\author{
WHEN THE CELLS ARE CURRICULUM:
}

A BOARDING ON THE RISK OF THE GENETIC DISCRIMINATION

Karina Meneghetti Brendler(1)

Liton Lanes Pilau Sobrinho ${ }^{(2)}$

\section{RESUMO}

O direito vive - porque deve viver - em constante mutação. Durante muitos séculos as mutações sociais foram lentas, tendo o direito seguido 0 mesmo ritmo. No entanto, no decorrer do século $X X$ as modificações sociais e científicas têm acontecido em velocidade cada vez mais acelerada, abrindo-se dessa forma um novo leque de estudo aos operadores jurídicos. Tanto é assim que tiveram e estão tendo considerável destaque as matérias envolvendo o meio ambiente, as relações de consumo, a informática, as novas descobertas ou avanços tecnológicos e científicos, entre muitos outros. $\dot{E}$ exatamente nesse contexto que se insere o presente estudo, que tem por finalidade analisar um tema bastante controvertido e que tem assumido grande relevância nos últimos tempos - a manipulação do patrimônio genético nos seres humanos e a conseqüente discriminação dai decorrente. Em relação à manipulação em seres humanos, existe, entre tantas outras, a possibilidade de uma conseqüente discriminação genética, baseada justamente na disparidade entre o fruto da criação natural e o ser manipulado, bem como na prévia identificação da carga genética de cada indivíduo.

\section{Palavras-chave}

Genoma Humano, Bioética, Discriminação Genética.

(1) Pós-Graduanda em Direito de Familia pela Universidade de Santa Cruz do Sul - UNISC.

(2) Coordenador de Pós-Graduaçāo da Faculdade de Direito da Universidade de Passo Fundo UPF, Membro do Centro Euro-Americano de Direito Constitucional e Mestre em Direito pela Universidade de Santa Cruz do Sul - UNISC. 


\section{ABSTRACT}

The law lives - because it must live - in constant mutation. During many centuries social mutations had been slow, and the law followed the same rhythm. However, in elapsing of this century the social and scientific modifications have happened in speed each sped up time more, confiding of this form a new fan of study to the legal operators. As much is thus, that they had had and they are having considerable has detached the substances involving the environment, the consumption relations, computer science, the new discoveries or technological and scientific advances, between many others. It is accurately in this context that if inserts the present study, that has for purpose to analyze a subject sufficiently controverted and that it has assumed great relevance in the last times - The manipulation of the genetic patrimony in the human beings and the consequent from there decurrent discrimination. In relation to the manipulation in human beings, it exists, between as much others, the possibility of one consequent based genetic discrimination exactly in the disparity enters the fruit of the natural creation and the manipulated being, as well as in the previous identification of the genetic load of each individual.

\section{Key-words}

Human Genoma, Bioethics, Genetic Discrimination.

\section{INTRODUÇÃO}

No final do segundo milênio, o homem presencia o maior avanço já visto no campo da engenharia genética. Mais do que isso, surpreende-se com o que se pode chamar de um "admirável mundo novo", que se materializa não só para as gerações futuras, mas já para as contemporâneas. O que até então era um território vedado ao conhecimento humano - a chave do mistério da vida - começou a ser descoberto.

Hoje - ou dentro em breve - a possibilidade de isolamento, manipulação e seleção genética é encarada como uma forma de terapia. Desse modo, quando uma criança nascer, será possivel traçar seu mapa genético e conhecer os males que ela estará predisposta a contrair durante a vida. Doenças degenerativas, como o mal de Alzheimer e o mal de Parkinson, e até mesmo doenças cardiacas, serão tratadas pela remoção ou alteração de genes ou da proteína que produz a enfermidade; outras, porém, serão evitadas com tratamentos preventivos, ou seja, se uma pessoa souber que suas chances de desenvolver câncer no pulmão são maiores do que a média, poderá evitar o cigarro. Da mesma forma, se o desejo dos genitores for de- 
senvolver uma criança mais bonita, mais inteligente ou mais forte, a terapia genética estará apta a auxiliá-los. Essas novas técnicas vão de certa forma modificar notavelmente o tratamento médico no futuro.

Sua admiração, todavia, não pode ser a venda que cega seus olhos para as implicações jurídicas e para os limites constitucionais que se devam impor a estes novos conhecimentos, muito especialmente em face do contexto e ordenamento jurídico vigentes.

Sobre isso leciona De Boni.

A tecnologia do DNA recombinante vem revolucionando a genética clinica e a indústria farmacêutica. Está em construção uma nova imagem do paciente e também da medicina. Aparece o doente assintomático, aquele que está com saúde hoje, mas com uma doença no genoma que poderá irromper futuramente. A identificação de um fator genético deficiente permitirá prevenir uma doença, atrasar seu aparecimento ou limitar seus efeitos. Trata-se da medicina preditiva aplicada à genética, em alto grau de desenvolvimento. Essas inovações, embora apresentando situações antes desconhecidas pela ética, não mudam seus conceitos nem seus princípios. A mídia, por razões que não cabe analisar agora, explora os aspectos sensacionalistas decorrentes das novas pesquisas. Deve-se reconhecer o caráter sensacionalista com que alguns destes temas são apresentados à sociedade, mas não podemos ignorar os perigos que o uso incontrolado destas técnicas envolve, pois a engenharia genética pode prever, prevenir e curar doenças, mas também pode gerar monstros, e, graças a isso, é mitificada e mistificada ${ }^{(3)}$.

De forma geral, pode ser afirmado que o uso atual da engenharia genética humana contribui para o aprofundamento dos princípios gerais da ética, já conhecidos. É evidente a repercussão ética das pesquisas da engenharia genética, trazendo questionamentos sérios, dentre os quais aqueles que diretamente balizam o presente estudo: como proceder diante das informações contidas no patrimônio genético dos indivíduos? Em contraponto, como proceder diante das discriminações genéticas que indubitavelmente ocorrerão a partir de tais conhecimentos?

Essas e outras perguntas que poderiam ser acrescentadas mostram a relação direta entre bioética e genética. Não se trata de dar respostas últimas e definitivas a esses questionamentos, mas sim, no parecer de $D$. Suzuki e $P$. Knudtson, "dar respostas provisórias que podem ao menos servir de subsídios para soluções mais significativas e precisas, que po-

(3) DE BONI, L. A., G. JACOB, F. SALZANO. Ética e genética. Porto Alegre: EDIPUCRS, 1998, p. 22. 
derão surgir nas décadas dos descobrimentos científicos que estão por $\operatorname{vir}^{\prime \prime(4)}$.

A partir de tais considerações, fica evidente o interesse existente na abordagem dos problemas relacionados com a genética. Aliás, uma amostra desse interesse apareceu no momento em que foi realizada uma pesquisa nos Estados Unidos pela Time/CNN(5). A constatação é a de que $75 \%$ dos entrevistados não querem que suas companhias de seguro de saúde conheçam seu código genético, por temerem discriminações, o que demonstra a relevância e a preocupação que vem o assunto despertando.

\section{Do patrimônio genético}

O patrimônio genético de um indivíduo consiste em toda a carga de informações sobre sua própria pessoa, que se encontra codificada nas células.

Dessa forma, o mapeamento do genoma humano significa muito mais do que uma conquista científica. Através dele, muito em breve, a humanidade terá sua rotina alterada a cada dia. Os remédios poderão prevenir doenças em vez de tentar curá-las. Os alimentos poderão conter nutrientes na quantidade necessitada pelo nosso corpo, evitando as doenças. As enfermidades poderão ser detectadas antes mesmo de aparecer, conduzindo a vida humana a uma longevidade jamais sonhada.

De fato, as possibilidades positivas são muitas, mas trazem consigo problemas também novos. Em pouco tempo o genoma humano não será assunto apenas de novas pesquisas, mas também ocupará os bancos dos tribunais. Pessoas diagnosticadas como portadoras de doenças graves poderão vir a ser discriminadas por companhias de seguros, em sua vida social, por empregadores e, até mesmo, em entrevistas de empregos, quando não será levada em conta a sua capacidade de trabalho, mas sim apenas e tão-somente a qualidade e as potencialidades do seu código genético.

\section{A evolução das descobertas genéticas}

A partir do momento em que nasce um ser humano, muitas previsões podem ser feitas em relação a seu futuro. Futuro este que naturalmente e num primeiro momento será determinado pela maneira como vai gerir suas

(4) SUZUKI, D., KNUDTSON apud CLOTET, Joaquim. Bioética como ética aplicada e genética. In: DE BONI, L. A., G. JACOB, F. SALZANO. Ética e genética. Porto Alegre: EDIPUCRS, 1998, p. 23.

(5) MAPA GENÉTICO CRIA NOVA ZONA DE DISCRIMINAÇÃO. Diário do Nordeste, Fortaleza, 13 fev. 2001. Internacional. Disponivel em: <http://www.uol.com.br/diariodonordeste/ 2001/02/13/ 010021.htm >. Acesso em 01 jun. 2001. 
próprias ações, mas que inarredavelmente será influenciado pelo ambiente ao redor. A ciência já foi capaz de demonstrar que muito do destino do homem já está predisposto antes mesmo do seu nascimento. O genoma do ser humano traz codificado no DNA ${ }^{(6)}$ dos seus 46 cromossomos as instruções que irão afetar não apenas a sua estrutura, seu tamanho, sua cor e outros atributos físicos, como também sua inteligência, sua suscetibilidade a doenças, seu tempo de vida e até aspectos do seu comportamento.

A propósito Linhares ensina que

(...) os genes são segmentos de moléculas de DNA com um código genético específico pela ordem de seus nucleotídeos. Situa-se em estruturas intranucleares chamadas de cromossomos. Alérn da dominância e da recessividade, existem diversos padrões de comportamento entre os genes, como a co-dominância, a interação gênica, a epistasia e outros. A espécie humana possui 23 pares de cromossomos. Cada gene possui um par de cromossomos, denominado lócus - local. Para cada posição que este gene ocupa no cromossomo, possuirá duas expressões genéticas, uma materna e outra paterna, que são os alelos. Ao conjunto de ambos dá-se o nome de genótipo; o que se poderá constatar externamente no individuo chama-se fenótipo ${ }^{(7)}$.

Todas aquelas caracteristicas, individuais e intrínsecas dos seres humanos e que são, em princípio, inafastáveis, chamamos de patrimônio genético da pessoa.

Desse modo, após décadas de laboriosos estudos, finalmente convergem para um fim comum as pesquisas e descobertas da ciência genética e biológica. Agora, realmente está se encaminhando para o fim o grande e profundo desafio das ciências genéticas: desvendar o segredo do genoma ${ }^{(8)}$ humano.

\section{Dessa forma,}

estas pesquisas vêm sendo aclamadas como a maior iniciativa científica desde a corrida para se enviar o homem à Lua. Em todo o globo, milhares de pesquisadores estão analisando as mensagens genéticas edificadas no DNA humano. Em 26 de junho de 2000 final-

(6) Sigla em inglês para ácido desoxirribonucléico, é uma molécula em formato de espiral composta por pares de bases nitrogenadas que correspondem às letras do código genético. O DNA é a matéria-prima dos cromossomos. Ordenado de forma especial em cada ser, diferencia um individuo de outro, como uma "marca registrada" genética que condiciona desde a cor dos olhos até a ocorrência de uma doença.

(7) LINHARES, S., GEWANDSZNAJDER, F. Biologia. São Paulo: Ática, 1983, p. 353.

(8) Conjunto de genes de um organismo, ou património genético armazenado no conjunto de seu DNA ou de seus cromossomos. Possui informações sobre as principais caracteristicas hereditárias, alteraçōes e doenças que o ser pode sofrer em sua vida. Conhecer e localizar os genes humanos possibilita intervir sobre aqueles responsáveis pelas doenças. 
mente o Projeto Genoma Humano e a empresa privada norte-americana Celera anunciaram a conclusão do mapeamento do Genoma Humano(9).

\section{O Projeto Genoma Humano}

O Projeto Genoma Humano tem como objetivo pesquisar, analisar e catalogar todo o conteúdo dos cromossomos humanos. Nestes termos, WiIkie assinala que:

É nada mais nada menos que a busca do completo entendimento da base genética do Homo Sapiens, incluindo a base genética das doenças. De posse desse conhecimento, o objetivo seguinte é aplicar tecnologia para alterar, quando preciso, algumas das instruções, visando aperfeiçoar o ser humano e livrá-lo de doenças e outros fatores limitantes ${ }^{(10)}$.

Isto posto, trata-se de um empreendimento internacional, iniciado formalmente em 1990 e projetado para durar 15 anos, tendo como objetivos principais identificar e fazer o mapeamento completo dos 80 mil genes que se calcula existirem no DNA das células do corpo humano, além de determinar as seqüências dos três bilhões de bases químicas que compõem o DNA humano e armazenar essas informações em bancos de dados, desenvolvendo ferramentas suficientes para analisá-los e torná-los acessiveis para novas pesquisas biológicas.

A iniciativa do Projeto Genoma partiu do setor público, tendo a liderança de James Watson, na época chefe dos Institutos Nacionais de Saúde dos EUA. Numerosas escolas, universidades e laboratórios participam do projeto, além de muitas empresas privadas de grande e pequeno porte.

Ao iniciar-se, em 1990, apenas 4.550 dos possiveis $60-80$ mil genes humanos haviam sido identificados. Apenas $2 \%$ dos genes (cerca de 1.500) haviam sido associados a localizações específicas nos 46 cromossomos. No entanto, atualmente, existem informações de que mais de $4 \%$ das bases do genoma humano já foram seqüenciadas, e espera-se concluir o Projeto na íntegra até o ano de 2003.

Mesmo assim, ainda não estando totalmente acabado, é possível antecipar alguns dos beneficios que o Projeto Genoma poderá trazer para a humanidade.

(9) CAPAZOLI, Ulisses. Projeto Genoma: a ciência de ponta no Brasil. Disponivel em: <http:// www.com-ciencia.br/reportagens/genoma/genoma7.htm>. Acesso em 01 jun. 2001.

(10) WILKIE, Tom. Projeto Genoma Humano. Um conhecimento perigoso. Rio de Janeiro: Jorge Zahar, 1993, contracapa. 
Na Medicina, o conhecimento sobre os genes contribui para a solução de doenças que envolvem um fator genético, como o câncer, por exemplo, levando a uma mudança da prática médica. Será dada ênfase à prevenção da doença, em vez do tratamento do doente. Novas tecnologias clínicas deverão surgir, baseadas em diagnósticos de DNA, como técnicas imunoterápicas, prevenção de doenças pelo conhecimento das condições ambientais que podem desencadeá-las, possível substituição de genes defeituosos por meio da terapia genética, entre outras inimagináveis.

Sem dúvida, o Projeto Genoma Humano é um fascinante e minucioso trabalho empreendido nas fronteiras do conhecimento científico atual. Devidamente aplicadas, suas descobertas poderão permitir a cura de doenças hereditárias para as quais há hoje poucas esperanças, bem como abrir caminhos para o tratamento de males que atingem toda a humanidade.

Os benefícios de tal projeto, de fato, estão sendo muito esperados e divulgados para a população mundial. No entanto, suas conseqüências e perigos são muito poucas vezes questionados, sendo, na maioria das vezes, ignorados.

Justamente por isso, faz-se pertinente o questionamento: será a sociedade capaz de lidar com a avalanche de novos conhecimentos que estão por vir? Estará a humanidade caminhando para um "Admirável Mundo Novo", como já previa Aldoux Huxley, em que os pais optarão pelo aborto seletivo até obter um filho cujo perfil genético indique grande inteligência? Levarão os testes genéticos ao surgimento de uma "subclasse" humana, sem acesso a empregos, assistência médica ou seguros? Justamente em busca de possiveis respostas é que se desenvolve o presente trabalho.

\section{A husca do ser humano perfeito}

É possível que no início dos tempos os ancestrais do homo sapiens não percebessem a razão nem a necessidade de reproduzir descendentes perfeitos.

Contudo, com o passar dos anos, os individuos começaram a apresentar as primeiras intenções e ímpetos de desenvolver o ser humano mais próximo possível da perfeição.

Historicamente ocorreram algumas passagens que bem demonstram essas afirmações. Com efeito, o nome que ficará sempre gravado na história da humanidade é o de Adolf Hitler, comandante-chefe do Terceiro Reich. Afora os motivos políticos embutidos nos ideais do Partido Nacional-Socialista dos Trabalhadores Alemães (nazismo), um dos principais motivos da ascensão do império de Hitler era a criação de uma raça perfeita e pura, livre 
de qualquer doença, todos brancos, com olhos claros, fortes, inteligentes e capazes.

Além destas, reportando-se à ficção científica, tem-se a obra literária Admirável Mundo Novo, de Aldous Huxley(11), que cria uma sociedade fictícia, um mundo marcado pelos avanços científicos, onde não mais existem relações familiares; todos são filhos de um só laboratório, e a ciência evoluiu a tal ponto que praticamente inexistem doenças ou enfermidades, produzindo-se indivíduos muito próximos da perfeição. No sonho ficcional, a reprodução deveria deixar o domínio da simples imitação da natureza para entrar no mundo "muito mais interessante" da invenção humana.

Saindo das concepções científicas de perfectibilização do ser humano, eis que, posteriormente, no crepúsculo do século $X X$ e início do século $X X I$, com a evolução das ciências biomédicas e da tecnologia genética, a busca do ser humano perfeito, que sempre fora um sonho antigo, começa a deixar de ser tratada como mero projeto e passa verdadeiramente a ganhar espaço nas discussões atuais.

No momento em que já é dada a possibilidade de manipular outros homens, a humanidade começa a sonhar com a possibilidade de construir a humanidade perfeita.

Trata-se da chamada terapia genética aplicada aos que vão nascer. Por meio dela é possivel evitar ou eliminar doenças de diversos tipos e espécies que poderiam, oportunamente, atacar o indivíduo. Quanto a isso, biólogos afirmam que seria possivel poupar um futuro cidadão de desenvolver um câncer quando ele ainda estiver na fase de mais incipiente formação, logo que o óvulo for fertilizado. O gene ficaria desligado até a doença se manifestar, e só então seria ativado por uma substância-gatilho, a ser tomada na ocasião.

Parece, a princípio, tratar-se de uma descoberta fantástica, que viria indubitavelmente a beneficiar o homem. Porém, assevera ainda o cientista que,

ao introduzir um gene num ovo, ele passaria a agir não apenas no bebê gerado por este ovo, mas também nos filhos desta criança e nos filhos dos filhos, ou seja, estaria dado o primeiro passo para a criação de uma geração de seres alterados geneticamente ${ }^{(12)}$.

Desse modo, certas alterações efetuadas num indivíduo não ficariam resiritas a ele, mas, ao contrário, passariam a afetar toda a geração seguinte.

(11) HUXLEY, Aldous. Admirável Mundo Novo. Tradução: Vidal de Oliveira e Lino Valandro. 22" ed. São Paulo: Globo, 1996.

(12) PEREIRA, C., PROPATO, V., FREITAS JR., O. Cegonha prêt-à-porter. Revista IstoÉ, n. 1.570, p. 129, nov. 1999. 
Questiona-se, porém, o perigo de que alguma pessoa, em vez de curar doenças, possua interesses em criar uma geração mais bonita, mais inteligente ou meramente mais adequada a certos padrões de comportamento.

Em nosso país, no entanto, a febre do bebê ou do ser humano perfeito ainda não chegou de forma tão declarada como nos Estados Unidos, até porque há a proibição da venda de óvulos e sêmen humano. Mesmo assim, esse tipo de procedimento tem gerado muita preocupação por parte dos profissionais da Medicina e dos legisladores. Uma delas é autorizar ou não os cientistas a brincar de Deus, deixando-os livres para criar novos organismos ou modificar os já existentes.

Tem-se, no entanto, que num assunto tão intrínseco às pessoas, como a geração de seus filhos, é difícil fazer qualquer espécie de julgamento. Certo é que todos têm expectativas de que seu bebê seja saudável, bonito e inteligente. Risco há, porém, quando se acaba elevando essas expectativas a extremos, como nos casos expostos.

Nas palavras do professor Volnei Garrafa, "ter um mundo de pessoas loiras, altas e magras é uma forma de 'purificação' da raça humana. Isso é Eugenia, prática condenável"(13).

\section{O genoma e a nova zona de discriminação}

Diante de todo o exposto, fica evidente que a decodificação do genoma já está desencadeando uma infinidade de questionamentos éticos e juridicos em todo o mundo. Ao mesmo tempo em que apresenta boas perspectivas, suscita questões que muito em breve passarão å ocupar o cotidiano dos tribunais.

Nas palavras de Lima Neto,

(...) é correto afirmar que a ciência tem uma face libertadora, a qual disponibiliza opções e conhecimentos para a solução de problemas, sendo que, podemos dizer, quanto maior o número de opções maior $o$ grau de liberdade do ser humano, e uma face destruidora, esta representada pelos males que a ciência pode trazer, estimulando os instintos e desejos mais egoístas e destrutivos dos povos, como se deu com a ameaça de uma hecatombe nuclear (...). Penso, todavia, que a força destrutiva que pode ser gerada pelo Projeto Genoma Humano se configura na maior ameaça que o ser humano neste atual mundo do mercado que prima pela exclusão, está fadado a enfrentar(14).

(13) Ibidem, p. 130.

(14) LIMA NETO, Francisco Vieira. Direito e discriminação genética. Disponivel em: <http:// www.mp.rj.gov.br/pesquisa/tema1-textos.htm>. Acesso em: $1^{2}$ jun. 2001. 
Em verdade, a possibilidade de leitura dos mapas genéticos inicia uma nova era das ciências médicas; entretanto, abre a possibilidade de a humanidade não estar preparada para esse conhecimento, criando uma nova zona de potencial discriminação.

Ainda no entendimento de Lima Neto:

Tendo em vista que o mapeamento dos genes do corpo humano terá por conseqüência a descoberta do papel de cada um deles, passamos a assistir, na atualidade, o surgimento de teorias discriminatórias, que defendem o determinismo genético e vêem o ser humano como um simples produto da soma de seus genes, abstraindo-se as influências do meio, em especial da cultura e do meio ambiente social e econômico em que vive ${ }^{(15)}$.

Os extremos e desvios, em um tipo de pesquisa e de evolução que deveriam estar voltado unicamente para o bem do homem, podem conduzir à exigência da perfeição, como pressuposto da boa e igual convivência em sociedade.

A partir do momento em que é possivel descobrir os defeitos e potencialidades de cada pessoa através de um simples exame genético, previsível passa a ser que esse conhecimento possa ser utilizado de forma não tão salutar como a ciência imaginara.

O jornal eletrônico Estadão, em reportagem, já previra que:

A história da eugenia é certamente uma advertência de que a humanidade pode não estar preparada para o conhecimento genético. Mas a ameaça imediata é a discriminação genética. Estamos só agora começando a identificar os "erros ortográficos" do código genético associados a doenças, mas vão passar-se anos entre esta descoberta e uma cura baseada no gene. Neste ínterim, as pessoas diagnosticadas como portadoras do mal podem ser discriminadas por companhias de seguros ou empregadores. Evidentemente a legislação sobre direitos humanos e direitos civis terá de incluir essa nova categoria de pessoa diagnosticada ${ }^{(16)}$.

De fato é provável que seguradoras e empregadores se vejam tentados a fazer mau uso dos avanços das pesquisas genéticas. Parece óbvio que, de posse de tais informações, seja lucrativo a uma empresa, exemplificativamente, num processo de seleção para funcionários, selecionar aque-

(15) Ibidem.

(16) DISCRIMINAÇÃO genética é uma ameaça imediata. Editorial. O Estadão, São Paulo, 28 jun. 2000. Disponivel em: <http://www.estado.com.br/editoriais/2000/06/28/ger410.html>. Acesso em: $1^{2}$ jun. 2001. 
les indivíduos que apresentem as características que mais convêm, ou então descartar indivíduos que tenham probabilidade de apresentar alguma doença ou mal incurável. Poderão aqueles economizar milhões se puderem utilizar o prognóstico genético para identificar com antecedência a refutar os operários ou candidatos a empregos predispostos a doenças crônicas.

De outro lado, apenas os empregadores beneficiar-se-ão com essas informações. Beneficiadas serão também, as empresas seguradoras de saúde, que poderão alterar os valores dos serviços ou até mesmo excluir clientes que demonstrarem propensões a determinadas doenças.

No Brasil o tema ainda é bastante recente. Porém, em países como os Estados Unidos o assunto já é largamente discutido, visto que casos práticos já estão chegando ao Judiciário.

A propósito, o jornal Diário do Nordeste, em interessante matéria, esclarece que:

Uma pesquisa da revista Time e a emissora de TV CNN disseram que no ano de $200075 \%$ de um total de 1.218 pessoas ouvidas disseram que não queriam que as empresas de seguros conhecessem seu código genético e $84 \%$ disseram que não queriam que o governo tivesse 0 acesso a esta informação. Entretanto, uma pesquisa realizada este ano pela Associação Americana de Administradores, efetuada com 2.133 empregadores, mostrou que sete estavam usando análises genéticas de seus funcionários e dos candidatos a emprego $(\ldots)^{(17)}$.

\section{CONSIDERAÇÕES FINAIS}

Eleger conteúdo teórico com a finalidade de encerrar o presente trabaTho não é tarefa das mais fáceis, pois o tema enfrentado, sem dúvida, é assunto recente e desafiador ao mundo juridico, principalmente em se tratando do Brasil.

Assim sendo, não há falar em respostas definitivas ou conclusões, visto que muitas interrogaçōes foram e podem ser levantadas, e, certamente, grande parte de suas respostas virá deflagrar outras problemáticas, estimulando novas e estimulantes investigações.

(17) MAPA genético criou nova zona de discriminação. O Diário do Nordeste, Fortaleza, 13 fev. 2001. Disponivel em: <http://www.uol.com.br/diariodonordeste/2001/02/13/010021.htm>. Acesso em: 19 jun. 2001. 
Respeitando a proposta originária desta investigação, o que se procura é trazer à baila a preocupação com as implicações jurídicas que advirão com as recentes descobertas científicas acerca da desvendagem do genoma humano e da possibilidade da manipulação e da possibilidade de ocorrência de terapias genéticas em organismos humanos.

De fato, não se pode mais fugir ou fechar os olhos diante do vertiginoso avanço das ciências biomédicas. As terapias gênicas já são uma realidade, e juntamente com ela advirá uma infinidade de outras problemáticas.

A discriminação genética figura entre as principais conseqüências desse "liberalismo" da legislação acerca do tema. Na verdade, é possivel imaginar a possibilidade de alguns órgãos terem acesso a toda a seqüência genômica dos indivíduos. Dessa forma, se não existir controle quanto a esse apossamento, a probabilidade de discriminação foge da seara da ficção e assume contornos de realidade. A partir disso, se fazem necessários alguns questionamentos:

Havendo a possibilidade de ter acesso ao código genético de cada individuo, e podendo-se optar entre um indivíduo genomicamente superior, determinado a executar certas tarefas, por que se optaria por um ser dito "inferior"?

Não há de negar que existe realmente o risco da discriminação. Inevitavelmente, se essas práticas discriminatórias continuarem a se desenvolver no mesmo ritmo que as pesquisas do genoma, muito em breve será possível contar com uma "subclasse" de indivíduos, ou seja, aqueles geneticamente inferiores.

Tudo isso leva sem dúvida a crer que a discriminação genética pode e deve ser acrescentada à lista de outras formas de discriminação, como a racial, étnica, sexual, entre tantas outras constantes em nosso ordenamento, devendo, pois, figurar junto aos principios constitucionais ligados à nãodiscriminação e naqueles ligados à manutenção da tão almejada igualdade constitucional.

\section{REFERÊNCIAS BIBLIOGRÁFICAS}

1. BONAVIDES, Paulo. Curso de direito constitucional. $11^{\text {a }}$ ed. São Paulo: Malheiros, 2001.

2. BRASIL. Constituição: República Federativa do Brasil - 1988. Brasilia: Senado Federal/Saraiva, 1988.

3. CANOTILHO, José Joaquim Gomes. Direito constitucional e teoria da Constituição. 4a ed. Coimbra: Almedina, 1997. 
4. CAPAZOLI, Ulisses. Projeto Genoma: a ciência de ponta no Brasil. Disponível em: <http://www.comciencia.br/reportagens/genoma/genoma7.htm>. Acesso em 1ำ jun. 2001.

5. CARLIN, Volnei Ivo. Ética e bioética: novo direito e ciências médicas. Florianópolis: Terceiro Milênio, 1998.

6. CLOTET, Joaquim. Bioética como ética aplicada e genética. In: DE BONI, L. A., G. JACOB, F. SALZANO. Ética e genética. Porto Alegre: EDIPUCRS, 1998.

7. DISCRIMINAÇÃO genética é uma ameaça imediata. Editorial. O Estadão, São Paulo, 28 jun. 2000. Disponivel em: <http://www.estado.com.br/editoriais/ -2000/06/28/ger410.html>. Acesso em: 1ํ jun. 2001.

8. FERNANDES, Tycho Brahe. A reprodução assistida em face da bioética e do biodireito: aspectos do direito de família e do direito das sucessões. Florianópolis: Diploma Legal, 2000.

9. FRANÇA, Vladimir da Rocha. Questões sobre a hierarquia entre as normas constitucionais na Constituição de 1988. Disponível em: <http:// www1.jus.com.br/doutrina/texto.asp?id=135>. Acesso em 09 jul. 2001.

10. HUXLEY, Aldous. Admirável Mundo Novo. Tradução: Vidal de Oliveira e Liro Valandro. 22ª ed. São Paulo: Globo, 1996.

11. LIMA NETO, Francisco Vieira. Direito e discriminação genética. Disponível em: <http://www.mp.rj.gov.br/pesquisa/tema1-textos.htm>. Acesso em: $1 \%$ jun. 2001.

12. LUCAS DA SILVA, Fernanda Duarte Lopes. Princípio constitucional da igualdade. Rio de Janeiro: Lumen Juris, 2001.

13. MAPA genético criou nova zona de discriminação. O Diário do Nordeste, Fortaleza, 13 fev. 2001. Disponivel em: <http://www.uol.com.br/diariodonordeste/ 2001/02/13/010021.htm>. Acesso em: 1 jun. 2001.

14. MELLO, Celso Bandeira de. O conteúdo jurídico do princípio da igualdade. $3^{\mathrm{a}}$ ed. São Paulo: Malheiros, 1998.

15. MORAIS, Alexandre de. Direito constitucional. São Paulo: Atlas, 1997.

16. PEREIRA, C., PROPATO, V., FREITAS JR., O. Cegonha prêt-à-porter. Revista IstoE, n. 1.570, pp. 125-130, 1999.

17. SILVA, De Plácido e. Vocabulário jurídico. $12^{\mathrm{a}}$ ed. Rio de Janeiro: Forense, 1997. 